\title{
Bird Diversity, Density and Foraging Activities in a University Campus Landscape in Sarawak
}

\author{
AUDREY MEI FANG VOON, KU NOR AZLINA KU NASRADHI, MUSTAFA ABDUL \\ RAHMAN \& JAYASILAN MOHD-AZLAN*
}

Department of Zoology, Faculty of Resource Science and Technology, Universiti Malaysia Sarawak, 94300 Kota Samarahan, Sarawak, Malaysia

\begin{abstract}
A total of 77 species from 34 families was recorded from 11,863 observations from November 2012 to April 2013 (six months) within Universiti Malaysia Sarawak (UNIMAS) campus using line transect method. This bird list is dominated by Asian Glossy Starling (Aplonis panayensis) with 4,917 observations (41.45\%) followed by Eurasian Tree Sparrow (Passer montanus) with 867 observations (7.31\%) and Yellow-vented Bulbul (Pycnonotus goiavier) with 752 observations $(6.34 \%)$. This study reports higher diversity $\left(\mathrm{H}^{\prime}=2.5\right)$ compared to previous studies. Density of bird was estimated at 6.24 individuals/ha. In order to explore the interspecific interactions between species, 19 bird species with (1,189 observations) most observations were subjected to bipartite network analysis. Based on the network analysis it appears that birds partition food resources spatially and by food type. The highest niche overlap occurs between foraging technique $(0.61)$ while lower overlap was observed for height (0.44), types of food $(0.42)$ and foraging substrate $(0.42)$. This suggests that birds were exploiting similar resources but segregated spatially. Therefore birds are partitioning their niche to allow coexistence and to adapt to human modified landscape. This study has provided valuable information in characterising the assemblage and understanding the distribution of the birds in a campus landscape.
\end{abstract}

Keywords: bird diversity, density, line transect, foraging behavior, niche partitioning

\section{INTRODUCTION}

Studies on bird diversity are important to understand global conservation needs for avian community. Anthropogenic activities such as deforestation have resulted in avifauna losses (Sodhi, 2002) because some birds are very sensitive to rapid changes in their environment which causes habitat fragmented. Additionally forest birds are more sensitive to disturbance as their survival depends on the availability of forest resources (Zakaria \& Zamri, 2008).

Therefore birds can be a good biological indicator to monitor biodiversity and environmental impact caused by anthropogenic activities (Sorace \& Visentin, 2007). Degraded landscape often regarded as low value for conservation mainly due to its inability to support the full spectrum of biodiversity of a pristine environment. Nevertheless the importance of disturbed and degraded habitat such as in rural area for birds can ameliorate some localised biodiversity loss (Peh et al., 2006; Ramli et al., 2012). Landscape change especially to urban areas may cause fluctuation in bird species numbers and change in the community structure due to resource utilization and niche partitioning. Consequently by understanding the foraging ecology, resource use and community structure, much can be inferred from the community's coexistence (Asokan \& Ali, 2010).

The species richness and assembly of a local community within a defined habitat is generally determined by both species colonization with establishment of breeding populations and species loss through local extinction (Krebs, 2009). The composition of a local community is mostly determined by the characteristics of the source pool of species, which is sometimes influenced by random selections from regional pools (Wiens, 1989). Study on coexisting bird species, in tropical rainforest ecosystem; have 
shown that bird species partition food resources by using different foraging behaviours (Styring \& Hussin, 2004). Coexisting species in an assemblage separate their niche or ecological needs by partitioning resource along temporal, spatial and behavioural niche axes.

Approximately 630 species of birds have been recorded in Borneo (Myers, 2009). Their survival, diversity and distribution in Borneo are not uniform since it is influenced by the available habitats, threats, altitude and geological history (Gill 1990; MacKinnon \& Philipps, 1993; Myers, 2009). Most public universities in Malaysia have forest patches or green areas embedded in the campus area which in turn provides habitat for a diverse bird species. Bird checklist in Universiti Malaysia Sarawak (UNIMAS) Campus by Rahman \& Tuen (2006) did not include density estimation and the description of foraging behaviour. The birds may significantly differ in how they exploit the food resources which can reflect the community structure and assemblage. Although many bird surveys have been undertaken in Sarawak over the last decade, most have been reported in unpublished documents and theses (Arif \& Mohd-Azlan, 2014). Thus, this study provides new information on the avifauna structure in UNIMAS specifically on the diversity, density and patterns of foraging behaviour of selected species and supplements the previous surveys carried out several years ago, thereby providing a more comprehensive baseline data-set for monitoring understorey bird populations within an urban setting.

\section{MATERIALS \& METHODS}

\section{Study Area}

UNIMAS campus is located $\left(1^{\circ} 27^{\prime} 53^{\prime \prime} \mathrm{N}\right.$

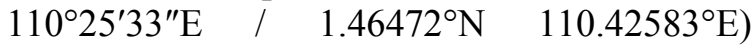
approximately $30 \mathrm{~km}$ from Kuching city and covers approximately 2,000 ha. Habitat features can create bird's structural complexity. Most of the roads along the campus are planted with exotic ornamental trees. The campus area is surrounded by secondary and heavily drained mix peat swamp forests. A small tidal influenced river runs through the campus has created a thin strip of mangrove habitat along the river. This has resulted in a diverse vegetation type including mangrove plants (i.e Avicennia spp., Sonneratia spp., Nypa fruticans, Rhizophora spp.) and ornamental urban trees such as Spanish cherry (Mimusops elengi) (Zainudin et al., 2012), Macarthur palm (Ptychosperma macarthurii), Fig/Ficus tree (Ficus benjamina) and Acacias (Acacia mangium and Acacia auriculiformis).

\section{Sampling Method}

Variable width transects were adopted for counting and evaluating bird density in this study. Distance sampling is more efficient than mist netting in bird studies (Zakaria \& Rajpar, 2010). Distance sampling method (Thomas et al., 2013) is useful for estimating abundance or density of bird population in a particular area (Bibby et al., 1992; Zhang, 2011). According to Buckland et al. (2001), various assumptions about the detectability of birds apply to variable width transect sampling. These assumptions are: 1) A large number of transects are randomly allocated in the study area independently of the distribution of the survey population, 2) All individuals on the line are detected with certainty $(\mathrm{g}(0)=1), 3)$ bird movement is slower compared to observer movement, 4) Objects are not counted twice in a single transect walk, 5) Objects do not move before being detected, and 6) Distances and angles are measured without error. To reduce observer bias and to avoid possible inter-observer variability, all the censuses were conducted by a single observer. Movement of birds that is independent of the observer is less problematic for line transects sampling because the average speed of the birds is around half the speed of the observer. Therefore, bias is small (Buckland et al., 2001).

The observer walked along transects during early morning (0630-1030 hours) and late evening (1600-1830 hours) for six times per month from $11^{\text {th }}$ November 2012 to $17^{\text {th }}$ April 2013. To avoid counting the same birds twice, transect were spaced at least $250 \mathrm{~m}$ apart. The presence of birds along predetermined transect line (about $6 \mathrm{~km}$ ) along the roadside were observed using binoculars (MEADE 8X42 Glacier) by applying Webb's method. A compass (Sunnto KB-14/360R) was used to estimate the angle $(\theta)$ between the transect line and the sighting distance $(x)$ from the observer to the bird were measured by using rangefinder Bushnell (7x26) at each point of the transect line where the bird was observed to reduce error in 
estimating distance and angle. The perpendicular distance $(\mathrm{d})$ from the transect line to the point the bird observed was later calculated using:

$$
\mathrm{d}=x \sin \theta
$$

The foraging behaviour parameters was described based on four basic components: (i) foraging height (0 m (ground), 0-2 m, 2-4 m, 4$6 \mathrm{~m}, 6-8 \mathrm{~m}$ and above $8 \mathrm{~m}$ ); (ii) foraging substrates (trunk, dead branch, branch, twig, foliage (include the leaf blades and petioles), fruit, flower, air, building and ground); (iii) the type of foods they forage (fruit, seed, nectar, pollen, foliage, insect, and human food left) and (iv) foraging techniques (glean, probe, snatch, hawk, pounce, and poke). Glean is to take food items from a nearby substrate (Cueto \& Casenave, 2002) without full extension of the legs or neck (Chen, 2008) and the food is picked directly from the substrate by a standing or hopping (Somasundaram \& Vijayan, 2008). Probe is when the bird inserts its bill into cracks or holes or directly into soft surfaces (Sodhi et al., 1997); snatch is to obtain prey by short flight or hop from perch (Soh, 2001); hawk is chasing the flying prey (Noske, 1996); pounce is grabing the food items on ground substrate after flies from a perch (Somasundram \& Vijayan, 2008) and poke is penetrate the bill into substrate (Sodhi et al., 1997). Only birds with more than 10 foraging observations were considered for further analysis (Mohd-Azlan et al., 2014). Feeding guild is defined as the group of species that exploit the same class of environmental resources in the similar way (Simberloff \& Dayan, 1991). Foraging birds were classified based on their feeding guild which depends on the type of foods (fruit, seed, nectar, pollen, foliage, insect, human food left) they forage and from the literature (MacKinnon \& Phillips, 1993). The size of prey item (small: $<1 \mathrm{~cm}, 1 \mathrm{~cm}>$ medium $<3 \mathrm{~cm}$ and large: $>3$ $\mathrm{cm})$ were recorded. The principle habitat where these birds were found was sourced from the literature (Phillipps \& Phillipps, 2014).

\section{Statistical Analysis}

DISTANCE 6.0, PAST (Paleontological Statistics) and EstimateS Win 8.2 were used for numerical analysis such as density, diversity and rarefaction respectively. DISTANCE 6.0 program will draw out each detection curve based on bird observations and then fit a mathematical model to it. In this study the halfnormal key function was fitted to the ungrouped, non-truncated data (distance $w$ was at least as large as the largest recorded distance) with cosine series of expansion and found to fit well (Buckland et al., 2001). DISTANCE 6.0 takes into account the variation among species in their detectability (by modelling the sighting distance frequency distributions as a measure of the attenuation in detectability with increasing sighting distances). The delectability function was used to estimate density using the following equation:

$$
D=\frac{n}{2 w L P_{a}} \times 10000=\text { individuals } / \text { ha }
$$

where $D$ is density (estimated number of bird individuals per unit area), $n=$ sample size or number of birds detected, $L=$ the total line length in a transect line survey $(\mathrm{m}), w=$ half the effective transect width $(\mathrm{m})$ where the distances exceeding $w$ either are not recorded or are truncated before analysis, $P a=$ the probability that a randomly selected object in the surveyed area $a$ is detected.

Shannon Diversity Index $\left(\mathrm{H}^{\prime}\right)$ which report species richness was used as it has a moderate ability to discriminate between communities and a low sensitivity to sample size (Magurran, 2004). Species richness asymptote was predicted by the randomization option of the program. The two level networks of interactions were tested between birds and resource dimensions using network analyses of the Bipartite package in $\mathrm{R}$ statistical computation and graphic (R Core Team, 2013). Bipartitepackage (Version 2.00), the two-mode networks aids to visualise the webs and calculate the ecological indices to describe the important features of the interaction between two trophic level (e.g. Madinah et al., 2014); higher level (e.g. bird species) and lower level (e.g. foraging technique, height, substrate, or type of food) (Mohd-Azlan et al., 2014). The niche overlap reveals the mean similarity in the interaction pattern between species of same trophic level and was calculated using Horn's index (1966). A multivariate Statistical Package, MVSP (Version 3.13d) was used to perform cluster 
analysis on the data matrix consisting of 19 species and 29 foraging-related characteristics. The analysis uses the nearest-neighbour clustering and Euclidean distance coefficients, following Sodhi et al. (1997).

\section{RESULTS \& DISCUSSION}

\section{Species Diversity and Density}

Bird surveys totaling 234 hours of observations along $216 \mathrm{~km}$ of transect lines provided 11863 observations which have resulted in 34 families and 77 species during the study period (Table 1). Morning surveys recorded more birds (calls and observation) compared to evening as bird's activities drops towards midday. As expected the Asian Glossy Starling recorded highest number of observations, with 4,917 observations $(47.45 \%)$ probably due to the localised movement of this species. The influx of Asian Glossy Starling during the present study period could be due to temporary abundance of edible fruits (e.g. Ficus benjamina), which are patchy in distribution and erratic in seasonality. This is followed by Eurasian Tree Sparrow with 867 observations $(7.31 \%)$. The availability of man-made lakes and small rivers have provided aquatic habitat and food sources for three species of kingfishers. The species accumulation graph shows increasing trends (Figure 1).

The IUCN (2013) red list categorized only six species $(7.8 \%)$ as near threatened while the remaining being listed as least concern (IUCN, 2013). Approximately $85 \%(n=65)$ of the birds in UNIMAS campus do not receive any protection under the Sarawak Wild Life Protection Ordinance (1998). Only 11 bird species are considered protected while the Cattle Egret is the only species that falls under the totally protected species category in the study area. Cuculidae represented most number of species $(n=8)$ followed by Ardeidae $(n=7)$ (Figure 2). Most of the families were represented by singletons $(n=8)$.

Forest birds (both primary and secondary forests) were the dominant bird species in the study area $(42.86 \%)$. This is followed by birds which are known to adapt to human habitation which recorded 21 species $(27.27 \%)$, followed by grassland birds $(\mathrm{n}=8 ; 10.39 \%)$, aquatic habitat $(\mathrm{n}=7 ; 9.09 \%)$, swamp $(\mathrm{n}=6 ; 7.79 \%)$, and mangrove forest $(\mathrm{n}=2 ; 2.60 \%)$. Bird species such as Zebra Dove, Eurasian Tree Sparrow and Oriental Magpie Robin were observed to utilize buildings, electrical wires, gardens and other human infrastructure. Grassland species was observed feeding on grassland small invertebrates such as insects, seeds and earthworm. Birds from the wetland areas such as peat swamp and mangrove forest were recorded in low densities.

The bird density was reliability estimated at 6.24 individuals/ha with a mean cluster size of 2.2 individuals with a detection probability of 3.4 (95\% confidence interval $=5.63$ and 6.90 , $\mathrm{CV}=5.12$, Effective Detection Area $=401.25$ $\mathrm{m})$. However, density estimation from small areas may yield bias estimates as small denominators in the ratio of number of birds to area give rise to high variability (Johnson, 2001). Additionally it is more likely to see birds in smaller patch due to reduced vegetation density and more individuals concentrating on few flowering and fruiting plants (Mohd-Azlan \& Lawes, 2011).

Current study reports the most comprehensive bird species list for UNIMAS campus when compared to previous studies which has employed similar method in estimating the species diversity and richness (e.g. Rahman \& Tuen, 2006). This study reports higher diversity $\left(\mathrm{H}^{\prime}=2.5\right)$ when compared to surveys done by Ridzuan (2006) $\left(\mathrm{H}^{\prime}=1.42\right)$ and Ghani (2008) $\left(H^{\prime}=1.1\right)$ and the findings are significantly different (Zar t-test, $\mathrm{P}<0.05$ ).

In comparison with birds in University Campus in Peninsular Malaysia, a total observation of 87 species recorded in green areas of University of Malaya (UM) Campus which consisted mainly of residents (80\%), migrants $(10 \%)$, and introduced species $(4.5 \%)$, with 22 species have been categorised as globally threatened (Ramli, 2004a). The difference between these two campuses is probably due to habitat complexity and surrounding matrices (e.g. Mohd-Azlan \& Lawes, 2011) which may have affected the distribution and composition of birds. Whereas in Universiti Kebangsaan Malaysia (UKM) a total of 91 bird species were captured by using mist-net method in the understorey of forest and forest edge in UKM, Bangi, Malaysia (KarimDakog et al., 1997). Thirty four of these bird 
Table 1. Birds observed throughout the study period in UNIMAS Campus and their guilds, habitat and conservation status according to IUCN (2013) and Sarawak Wild Life Protection Ordinance (1998) (SWLPO).

\begin{tabular}{|c|c|c|c|c|c|c|}
\hline Common Name & Scientific Name & $\begin{array}{l}\text { Observation } \\
\text { (n) }\end{array}$ & $\begin{array}{l}\text { IUCN } \\
\text { (2013) }\end{array}$ & $\begin{array}{l}\text { SWLPO } \\
(1998)\end{array}$ & $\begin{array}{c}\text { Feeding } \\
\text { guild }\end{array}$ & Habitat \\
\hline Pacific Golden Plover & Pluvialis fulva & 42 & LC & NL & $\mathrm{O}$ & GR \\
\hline Common Sandpiper & Actitis hypoleucos & 109 & LC & NL & $\mathrm{C}$ & $\mathrm{R}$ \\
\hline Wood Sandpiper & Tringa glareola & 1 & LC & NL & $\mathrm{C}$ & $\mathrm{R}$ \\
\hline Cattle Egret & Bubulcus ibis & 49 & LC & $\mathrm{TP}$ & $\mathrm{C}$ & GR \\
\hline Chinese Pond-Heron & Ardeola bacchus & 9 & LC & $\mathrm{P}$ & $\mathrm{C}$ & SW \\
\hline Cinnamon Bittern & $\begin{array}{l}\text { Ixobrychus } \\
\text { cinnamomeus }\end{array}$ & 14 & LC & $\mathrm{P}$ & $\mathrm{C}$ & SW \\
\hline Intermediate Egret & Mesophoyx intermedia & 55 & LC & $\mathrm{P}$ & $\mathrm{C}$ & GR \\
\hline Little Egret & Egretta garzetta & 76 & LC & $\mathrm{P}$ & $\mathrm{C}$ & SW \\
\hline Rufous Night-heron & Nycticorax caledonicus & 1 & LC & $\mathrm{P}$ & $\mathrm{C}$ & M \\
\hline Striated Heron & Butorides striata & 3 & LC & $\mathrm{P}$ & $\mathrm{C}$ & $\mathrm{R}$ \\
\hline Little Green Pigeon & Treron olax & 1 & LC & NL & $\mathrm{H}$ & $\mathrm{F}$ \\
\hline Pink-necked Green-pigeon & Treron vernans & 302 & LC & NL & $\mathrm{H}$ & $\mathrm{HH}$ \\
\hline Spotted Dove & $\begin{array}{l}\text { Stigmatopelia } \\
\text { chinensis/Streptopelia } \\
\text { chinensis }\end{array}$ & 302 & LC & NL & $\mathrm{H}$ & $\mathrm{HH}$ \\
\hline Zebra Dove & Geopelia striata & 231 & LC & NL & $\mathrm{H}$ & $\mathrm{HH}$ \\
\hline Black-capped Kingfisher & Halcyon pileata & 1 & LC & $\mathrm{P}$ & $\mathrm{C}$ & $\mathrm{R}$ \\
\hline Collared Kingfisher & Todiramphus chloris & 18 & LC & $\mathrm{P}$ & $\mathrm{C}$ & $\mathrm{HH}$ \\
\hline Stork-billed Kingfisher & Pelargopsis capensis & 33 & LC & $\mathrm{P}$ & $\mathrm{C}$ & $\mathrm{R}$ \\
\hline Asian Koel & $\begin{array}{l}\text { Eudynamys } \\
\text { scolopaceus }\end{array}$ & 1 & LC & NL & $\mathrm{H}$ & $\mathrm{F}$ \\
\hline Banded Bay Cuckoo & Cacomantis sonneratii & 2 & LC & NL & $\mathrm{C}$ & $\mathrm{F}$ \\
\hline Common Cuckoo & Cuculus canorus & 2 & LC & NL & $\mathrm{C}$ & GR \\
\hline Drongo Cuckoo & Surniculus lugubris & 4 & LC & NL & $\mathrm{C}$ & $\mathrm{F}$ \\
\hline Greater Coucal & Centropus sinensis & 14 & LC & NL & I & M \\
\hline Indian Cuckoo & Cuculus micropterus & 6 & LC & NL & $\mathrm{C}$ & $\mathrm{R}$ \\
\hline Plaintive Cuckoo & Cacomantis merulinus & 29 & LC & NL & $\mathrm{C}$ & $\mathrm{F}$ \\
\hline Violet Cuckoo & $\begin{array}{l}\text { Chrysococcyx } \\
\text { xanthorhynchus }\end{array}$ & 1 & LC & NL & $\mathrm{C}$ & $\mathrm{F}$ \\
\hline Bat Hawk & Macheiramphus alcinus & 41 & LC & NL & $\mathrm{C}$ & $\mathrm{F}$ \\
\hline Crested Serpent-eagle & Spilornis cheela & 2 & LC & NL & $\mathrm{C}$ & $\mathrm{F}$ \\
\hline Red Junglefowl & Gallus gallus & 16 & LC & NL & $\mathrm{O}$ & $\mathrm{HH}$ \\
\hline White-breasted Waterhen & $\begin{array}{l}\text { Amaurornis } \\
\text { phoenicurus }\end{array}$ & 243 & LC & NL & $\mathrm{O}$ & SW \\
\hline Common Iora & Aegithina tiphia & 73 & LC & NL & $\mathrm{H} / \mathrm{I}$ & $\mathrm{HH}$ \\
\hline $\begin{array}{l}\text { White-breasted } \\
\text { Woodswallow }\end{array}$ & Artamus leucorynchus & 128 & LC & NL & I & $\mathrm{HH}$ \\
\hline Pied Triller & Lalage nigra & 284 & LC & NL & I & $\mathrm{HH}$ \\
\hline Yellow-bellied Prinia & Prinia flaviventris & 101 & LC & NL & I & $\mathrm{HH}$ \\
\hline Slender-billed Crow & Corvus enca & 7 & LC & NL & $\mathrm{O} / \mathrm{S}$ & $\mathrm{F}$ \\
\hline Orange-bellied Flowerpecker & Dicaeum trigonostigma & 11 & LC & NL & $\mathrm{H} / \mathrm{I}$ & $\mathrm{HH}$ \\
\hline Red-chested Flowerpecker & Dicaeum maugei & 1 & LC & NL & $\mathrm{H} / \mathrm{I}$ & $\mathrm{F}$ \\
\hline Scarlet-backed Flowerpecker & Dicaeum cruentatum & 1 & LC & NL & $\mathrm{H} / \mathrm{I}$ & SW \\
\hline
\end{tabular}




\begin{tabular}{|c|c|c|c|c|c|c|}
\hline $\begin{array}{l}\text { Scarlet-breasted } \\
\text { Flowerpecker }\end{array}$ & Prionochilus thoracicus & 3 & NT & NL & $\mathrm{H} / \mathrm{I}$ & $\mathrm{F}$ \\
\hline Yellow-breasted & Prionochilus maculatus & 2 & $\mathrm{LC}$ & NL & $\mathrm{H} / \mathrm{I}$ & $\mathrm{F}$ \\
\hline Flowerpecker & & & & & & \\
\hline $\begin{array}{l}\text { Greater Racket-tailed } \\
\text { Drongo }\end{array}$ & Dicrurus paradiseus & 3 & $\mathrm{LC}$ & NL & I & $\mathrm{F}$ \\
\hline Lesser Racket-tailed Drongo & Dicrurus remifer & 1 & $\mathrm{LC}$ & NL & I & $\mathrm{F}$ \\
\hline Chestnut Munia & Lonchura atricapilla & 526 & $\mathrm{LC}$ & NL & $\mathrm{H}$ & GR \\
\hline Dusky Munia & Lonchura fuscans & 221 & $\mathrm{LC}$ & NL & $\mathrm{H}$ & GR \\
\hline Scaly-breasted Munia & Lonchura punctulata & 261 & $\mathrm{LC}$ & NL & $\mathrm{H}$ & GR \\
\hline Black-and-red Broadbill & $\begin{array}{l}\text { Cymbirhynchus } \\
\text { macrorhynchos }\end{array}$ & 1 & $\mathrm{LC}$ & NL & $\mathrm{H} / \mathrm{I}$ & $\mathrm{R}$ \\
\hline Pacific Swallow & Hirundo tahitica & 433 & $\mathrm{LC}$ & NL & I & $\mathrm{HH}$ \\
\hline Asian Fairy-bluebird & Irena puella & 1 & $\mathrm{LC}$ & NL & $\mathrm{H} / \mathrm{I}$ & $\mathrm{F}$ \\
\hline Long-tailed Shrike & Lanius schach & 87 & $\mathrm{LC}$ & NL & I & $\mathrm{HH}$ \\
\hline Australasian Pipit & Anthus novaeseelandiae & 36 & $\mathrm{LC}$ & NL & I & GR \\
\hline Oriental Magpie-robin & Copsychus saularis & 161 & $\mathrm{LC}$ & NL & I & $\mathrm{HH}$ \\
\hline Crimson Sunbird & Aethopyga siparaja & 4 & $\mathrm{LC}$ & NL & $\mathrm{N}$ & $\mathrm{F}$ \\
\hline Little Spiderhunter & $\begin{array}{l}\text { Arachnothera } \\
\text { longirostra }\end{array}$ & 3 & $\mathrm{LC}$ & NL & $\mathrm{N}$ & $\mathrm{F}$ \\
\hline Olive-backed Sunbird & Nectarinia jugularis & 184 & $\mathrm{LC}$ & NL & $\mathrm{N}$ & $\mathrm{HH}$ \\
\hline Plain-throated Sunbird & Anthreptes malacensis & 272 & $\mathrm{LC}$ & NL & $\mathrm{N}$ & $\mathrm{HH}$ \\
\hline Purple-naped Sunbird & $\begin{array}{l}\text { Hypogramma } \\
\text { hypogrammicum }\end{array}$ & 3 & $\mathrm{LC}$ & NL & $\mathrm{N}$ & $\mathrm{F}$ \\
\hline Eurasian Tree Sparrow & Passer montanus & 867 & $\mathrm{LC}$ & NL & $\mathrm{H}$ & $\mathrm{HH}$ \\
\hline Cream-vented Bulbul & Pycnonotus simplex & 5 & $\mathrm{LC}$ & NL & $\mathrm{H} / \mathrm{I}$ & $\mathrm{F}$ \\
\hline Olive-winged Bulbul & Pycnonotus plumosus & 6 & $\mathrm{LC}$ & NL & $\mathrm{H} / \mathrm{I}$ & $\mathrm{F}$ \\
\hline Red-eyed Bulbul & Pycnonotus brunneus & 9 & $\mathrm{LC}$ & NL & $\mathrm{H} / \mathrm{I}$ & $\mathrm{F}$ \\
\hline Yellow-vented Bulbul & Pycnonotus goiavier & 752 & $\mathrm{LC}$ & NL & $\mathrm{O} / \mathrm{S}$ & $\mathrm{HH}$ \\
\hline Pied Fantail & Rhipidura javanica & 36 & $\mathrm{LC}$ & NL & I & $\mathrm{HH}$ \\
\hline Spotted Fantail & Rhipidura perlata & 1 & $\mathrm{LC}$ & NL & I & $\mathrm{F}$ \\
\hline Asian Glossy Starling & Aplonis panayensis & 4917 & $\mathrm{LC}$ & NL & $\mathrm{O} / \mathrm{S}$ & $\mathrm{HH}$ \\
\hline Common Myna & Acridotheres tristis & 611 & $\mathrm{LC}$ & NL & $\mathrm{O} / \mathrm{S}$ & $\mathrm{HH}$ \\
\hline Hill Myna & Gracula religiosa & 3 & $\mathrm{LC}$ & $\mathrm{P}$ & $\mathrm{O}$ & $\mathrm{F}$ \\
\hline Ashy Tailorbird & Orthotomus ruficeps & 119 & $\mathrm{LC}$ & NL & I & $\mathrm{F}$ \\
\hline Rufous-tailed Tailorbird & Orthotomus sericeus & 38 & $\mathrm{LC}$ & NL & I & $\mathrm{HH}$ \\
\hline Chestnut-winged Babbler & Stachyris erythroptera & 8 & $\mathrm{LC}$ & NL & I & $\mathrm{F}$ \\
\hline Rufous-crowned Babbler & Malacopteron magnum & 6 & NT & NL & I & $\mathrm{F}$ \\
\hline Striped tit-Babbler & Macronous bornensis & 47 & $\mathrm{LC}$ & NL & I & $\mathrm{F}$ \\
\hline Striped Wren-Babbler & Kenopia striata & 1 & NT & NL & I & $\mathrm{F}$ \\
\hline Oriental White-eye & Zosterops palpebrosus & 15 & $\mathrm{LC}$ & NL & $\mathrm{H} / \mathrm{I}$ & SW \\
\hline Blue-eared Barbet & Megalaima australis & 1 & $\mathrm{LC}$ & NL & $\mathrm{H}$ & $\mathrm{F}$ \\
\hline $\begin{array}{l}\text { Crimson-winged } \\
\text { Woodpecker }\end{array}$ & Picus puniceus & 1 & $\mathrm{LC}$ & $\mathrm{P}$ & I & $\mathrm{F}$ \\
\hline Red-crowned Barbet & Megalaima rafflesii & 3 & NT & NL & $\mathrm{H}$ & $\mathrm{F}$ \\
\hline Red-throated Barbet & $\begin{array}{l}\text { Megalaima } \\
\text { mystacophanos }\end{array}$ & 2 & NT & NL & $\mathrm{H}$ & $\mathrm{F}$ \\
\hline Yellow-crowned Barbet & Megalaima henricii & 1 & NT & NL & $\mathrm{H}$ & $\mathrm{F}$ \\
\hline TOTAL OBSERVATIONS & 11863 & & & & & \\
\hline TOTAL SPECIES & 77 & & & & & \\
\hline
\end{tabular}




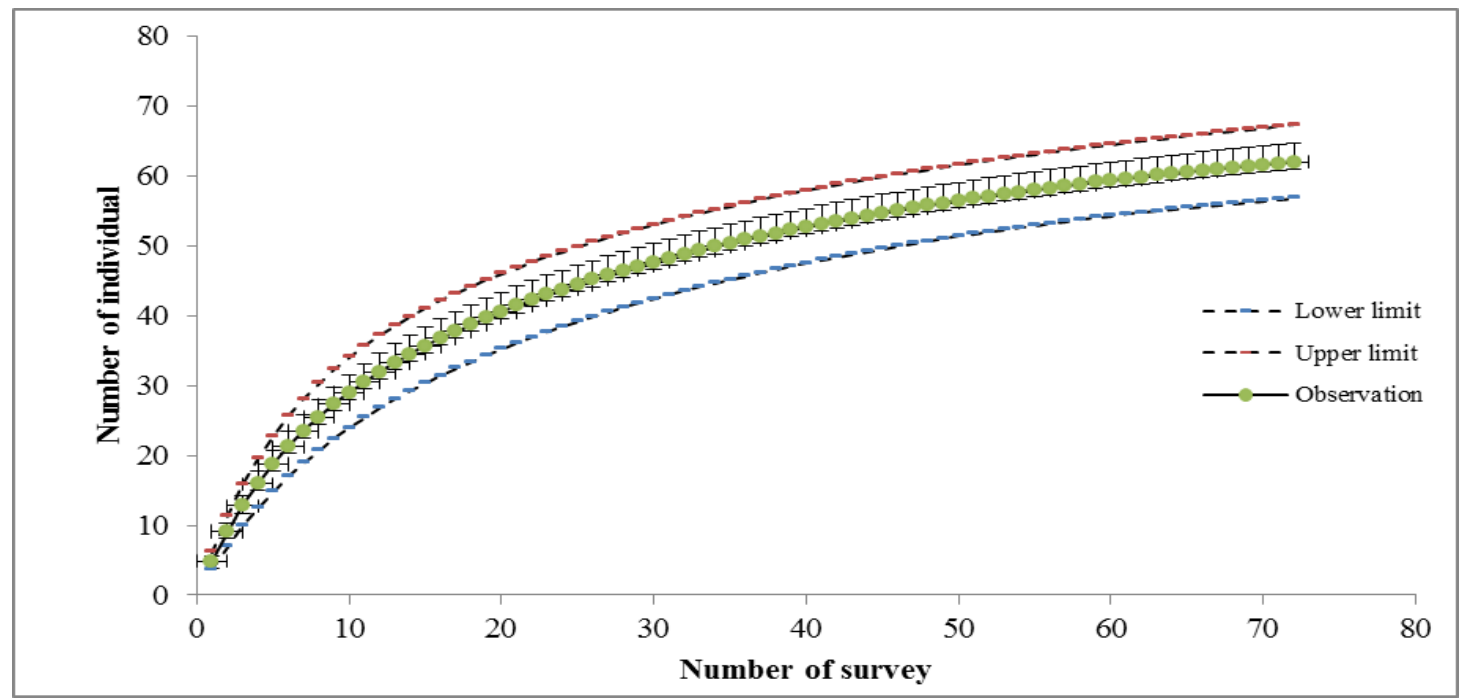

Figure 1. Rarefaction of species accumulation curve of bird species recorded in UNIMAS campus shows little sign of reaching an asymptote, suggesting additional surveys could produce comprehensive bird list for the study area. Standard deviation is denoted by the whiskers.

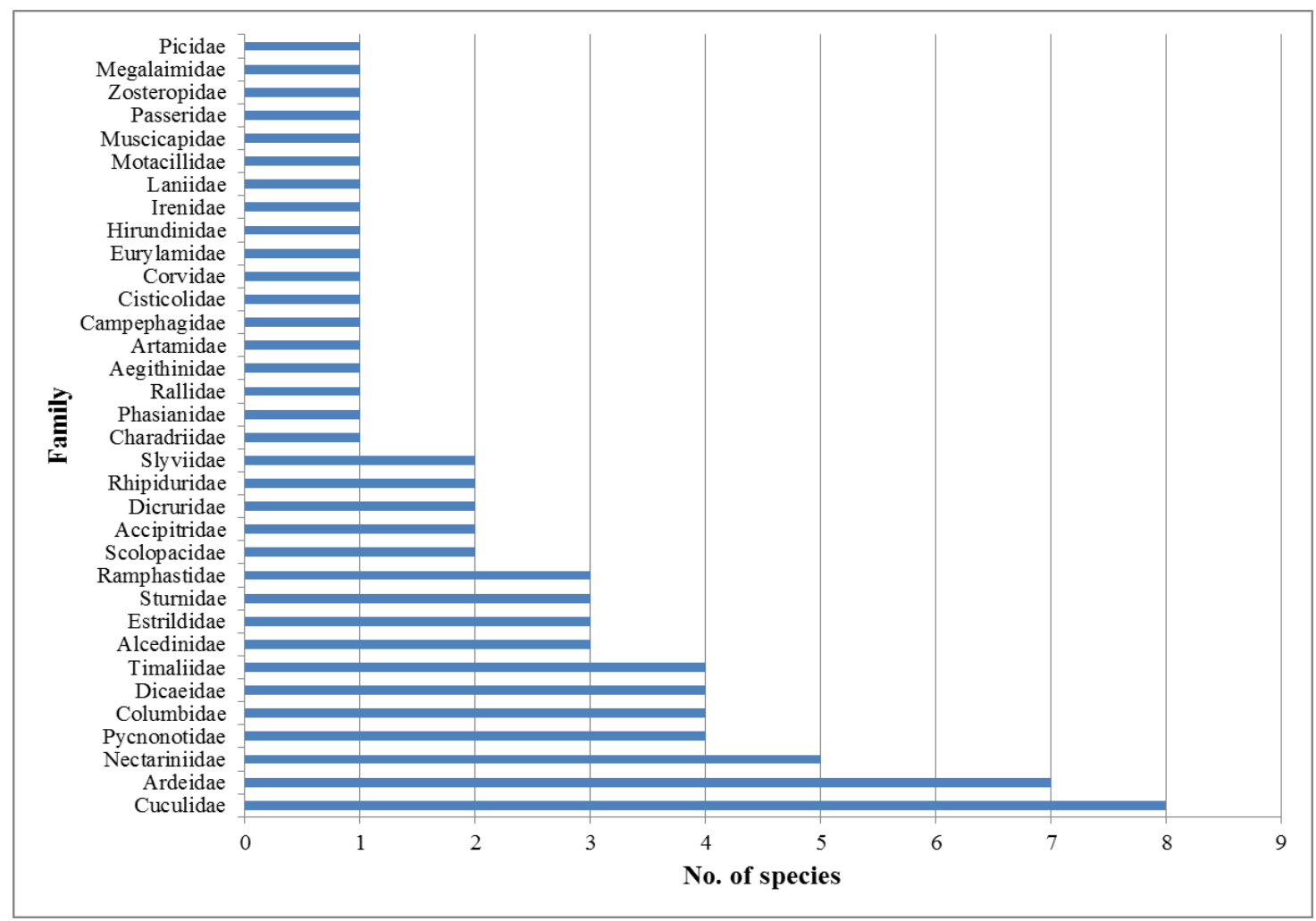

Figure 2. Number of bird species according to families recorded in UNIMAS campus between $11^{\text {th }}$ November 2012 to $17^{\text {th }}$ April 2013. 
species were non-forest species. The most common species are bulbuls which comprised of $32 \%$ whereas the predominant guild was insectivorous. In general bird species composition in peat swamp forest are different when compared to rainforest. This may partly have contributed the low bird diversity in UNIMAS when compared to UM and UKM which mostly consisted of regenerating secondary forest. Generalist species such as Eurasian Tree Sparrow and Yellow-vented Bulbul were recorded at both sites because they are more efficient in scavenging any available resources from the surrounding environment. The adaptability of Asian Glossy Starling and Eurasian Tree Sparrow to use buildings for nesting and scavenging on food waste has enabled them to co-exist with human and development. In addition to this birds composition recorded in both UNIMAS and selected forested urban area in Peninsular Malaysia has been reported as generalist and smaller in size (Ramli, 2004b; Ramli et al., 2012). Similar to this study Ramli et al. (2012) recorded 70 species of birds which are mostly associated with open country, garden and parks, mangrove and lowland in a rural area in Northern Peninsula Malaysia.

\section{Foraging Ecology}

Most of the birds in UNIMAS campus were carnivores (20 species; 25.97\%) followed by omnivores (20.78\%), insectivores (24.68\%), and herbivores (16.88\%) (Table 1). Nectarivores and omnivores/ scavengers were represented by five (6.49\%) and four species (5.19\%) respectively. Carnivores such as kingfishers, egrets, cuckoo and eagles were feeding mostly on small vertebrates. Nectarivores were represented by sunbirds and spiderhunters which fed on nectar of Mimusops elengi which is abundant in the campus area. Omnivores/ scavengers record the least number of species, mostly from the family Sturnidae. These species were observed scavenging along the roadside.

High flexibility in interactions within the campus area suggests that, to persist and coexist in urban area, most birds adopt an opportunistic and generalist use of resources. Thus, partitioning of foraging dimension occurred in the bird assemblage within UNIMAS Campus. Network analysis (Figure 3) showed that the highest niche overlap occur between foraging technique $(0.61)$ as 18 species from 733 observation $(61.65 \%)$ used gleaning technique to forage. However, lower overlap was recorded for spatial dimension such as foraging height (0.44), substrate (0.42) and type of food (0.42). It is evident that the birds were segregated spatially to reduce competition while coexisting in the same habitat (Figures 3, 4, and 5) (Mansor $\&$ Sah, 2012). The findings also suggest birds are exploiting the food resources in an opportunistic fashion which possibly leads to considerable variation in food resource use and interspecific overlaps in other resource axes.

Generalist species such as Asian Glossy Starling and Yellow-vented Bulbul forages at various levels and on different substrates by using different techniques. All species of Munia are specialist (granivores) and often gleaned either on ground or on foliage in the shrub layers. Long-tailed shrike (Lanius schach), a new record for the campus was often foraged in the shrubs or open area near the roadside. This species normally utilizes sit and wait strategy before attacking their prey such as butterflies, wasps, grasshoppers, and larvae through gleaning, snatching, pouncing or hawking. Species such as Common Iora (Aegithina tiphia), Ashy Tailorbird (Orthotomus ruficeps) and Pied Triller (Lalage nigra) preyed on smaller insects.

Multivariate analysis showed that bird species were clustered together due to some similarities in foraging behaviour and guild (Figure 6). For example, Olive-backed Sunbird (Nectarinia jugularis) and Plain-throated Sunbird (Anthreptes malacensis) were closely related because both are nectarivores and utilises nectar from the same source [e.g. Pink tecoma (Tabebuian pentaphylla), Goa tree (Andira surinamensis), Rain tree (Samanea saman), and Spanish cherry (Mimusops elengi)].

It is suggested that the density and diversity of birds in UNIMAS campus was mainly influenced by microhabitat, food sources and habitat heterogeneity. Most of the species recorded in the study area consist of forest dependent species. Foraging profile indicates the importance of spatial partitioning (i.e. foraging height, foraging substrate) and type of food 
which influenced the community structure in UNIMAS campus. Degraded forest such as within the campus should not regarded as low valued forest (Ghani et al., 1999; Ramli et al., 2012) as this habitat can provide a refugia for bird species from neighbouring habitat which is rapidly being converted to township. Additional sampling is suggested especially during the drier season (May to October) in order to understand the population trend of bird assemblage in UNIMAS campus.

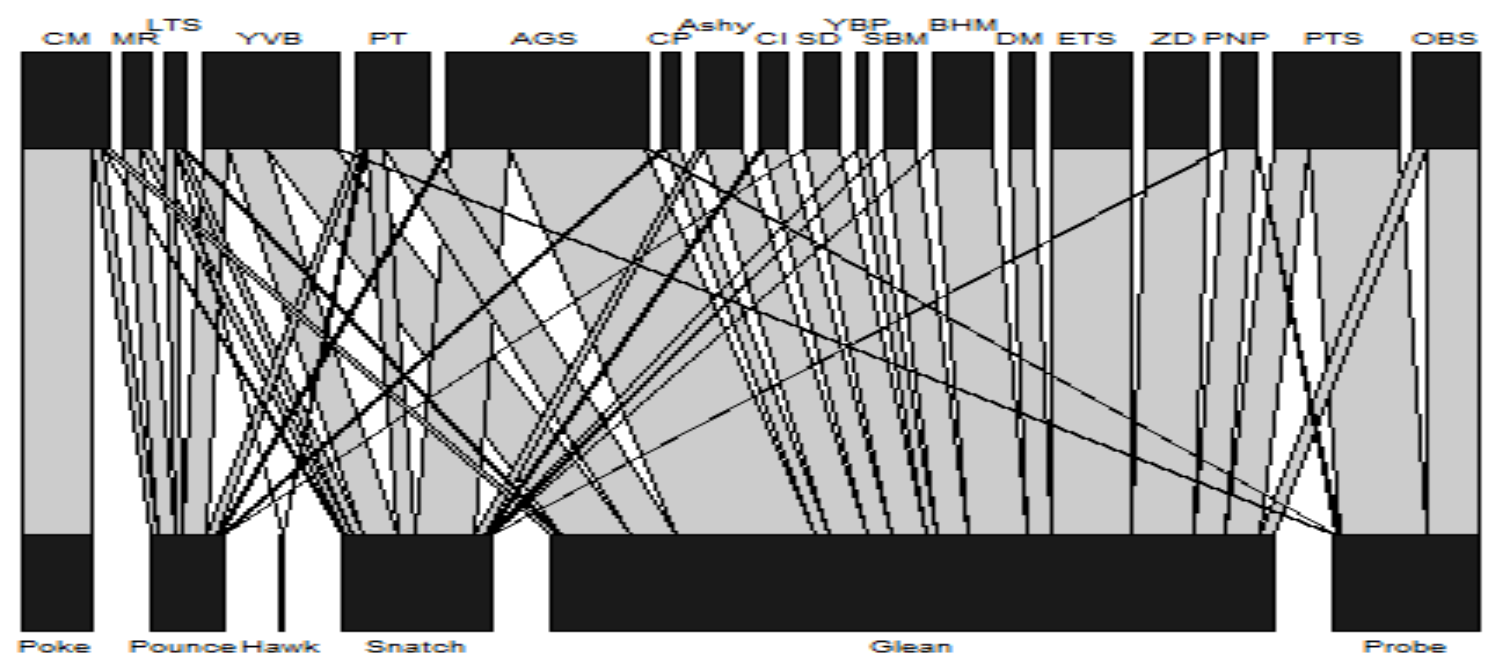

Figure 3. Bipartite graph shows the interaction between foraging technique and bird species $(\mathbf{P N P}=$ PinkNecked Green Pigeon, $\mathbf{C I}=$ Common Iora, AGS $=$ Asian Glossy Starling, $\mathbf{P T S}=$ Plain Throated Sunbird, $\mathbf{O B S}=$ Olive-Backed Sunbird, Ashy $=$ Ashy Tailorbird, PT $=$ Pied Triller, YBP= Yellow Bellied Prinia, YVB= YellowVented Bulbul, SBM= Scaly-Breasted Munia, BHM= Black-Headed Munia, DM= Dusky Munia, LTS= LongTailed Shrike, MR= Magpie Robin, ETS= Eurasian Tree Sparrow, SD=Spotted Dove, CM=Common Myna, $\mathbf{Z D}=$ Zebra Dove, $\mathbf{C P}=$ Common Pipit). Widths of links are scaled in relation to interaction frequencies, bar sizes to total interaction frequencies.

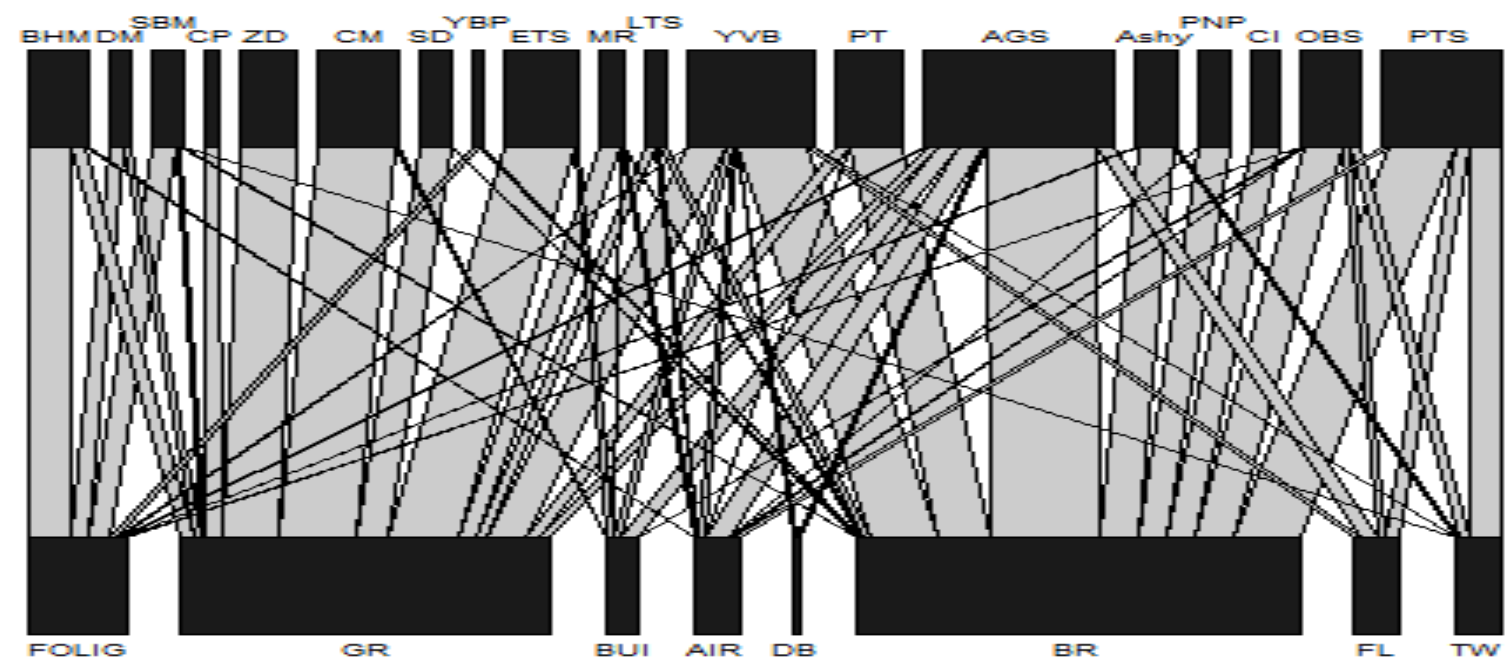

Figure 4. Bipartite graph shows the interaction between foraging substrates $(\mathbf{F O L I G}=$ foliage, $\mathbf{G R}=$ ground, $\mathbf{B U I}=$ building, $\mathbf{A I R}=$ Air, $\mathbf{D B}=$ dead branch, $\mathbf{B R}=$ branch, $\mathbf{F L}=$ flower, $\mathbf{T W}=$ twig) and bird species (For species acronyms refer to Figure 3). Widths of links are scaled in relation to interaction frequencies, bar sizes to total interaction frequencies. 


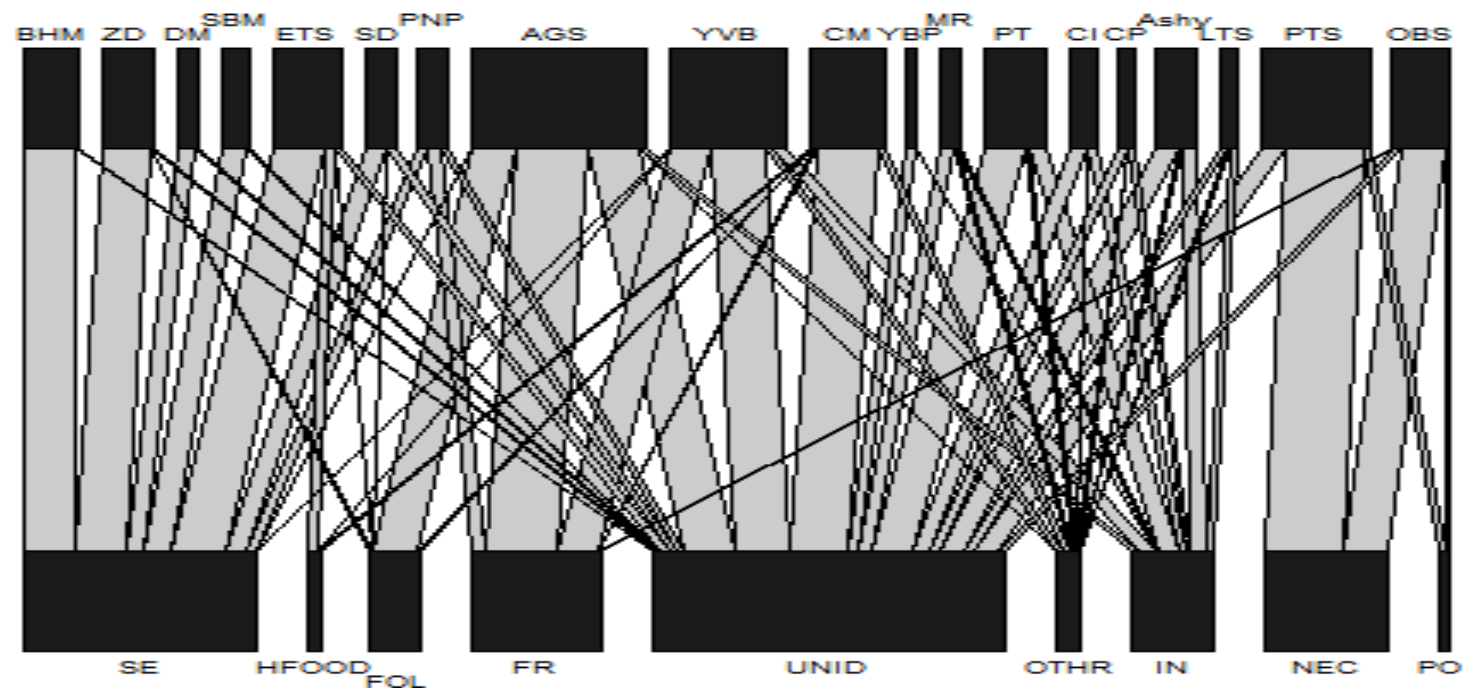

Figure 5. Bipartite graph shows interaction between types of food $(\mathbf{S E}=$ seed, HFOOD $=$ human food, $\mathbf{F O L}=$ foliage, $\mathbf{F R}=$ fruit, $\mathbf{U N I D}=$ unidentified, $\mathbf{O T H R}=$ other invertebrate, $\mathbf{I N}=$ insect, $\mathbf{N E C}=$ nectar, $\mathbf{P O}=$ pollen) and bird species (For species acronyms refer to Figure 3). Widths of links are scaled in relation to interaction frequencies, bar sizes to total interaction frequencies.

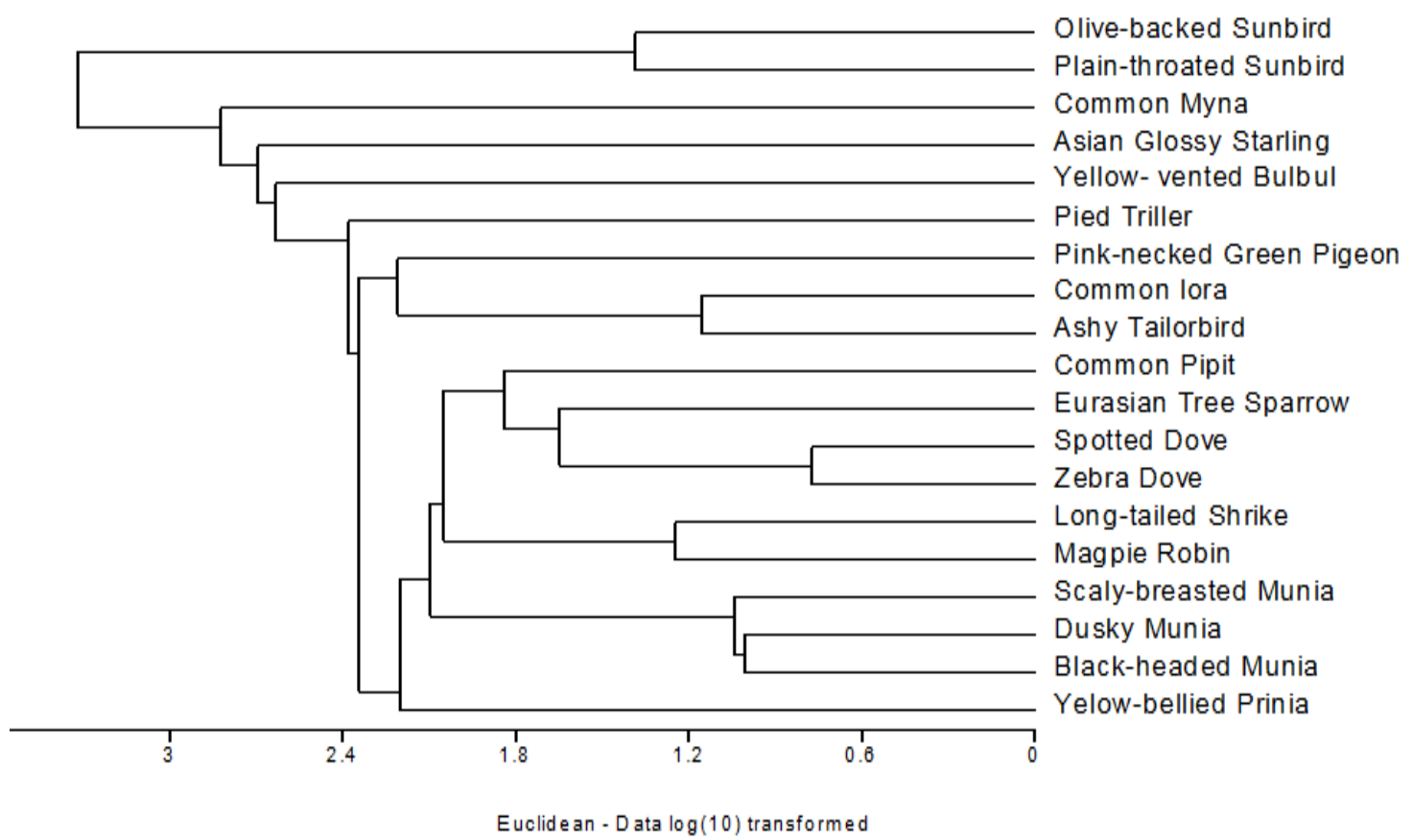

Figure 6. Dendrogram of nearest-neighbour cluster based on the foraging behaviour groups species of similar guilds. 


\section{ACKNOWLEDGEMENT}

The authors acknowledge the support received from the Faculty Resource Science and Technology, UNIMAS (NRGS/1088/2013(01)). We also thank Mr. Isa Sait for his invaluable assistance in the field.

\section{REFERENCES}

Arif, N.A. \& Mohd-Azlan J. (2014). Diversity of birds captured by mist-netting in the understorey of Gunung Gading National Park, Sarawak, Borneo. Kukila, 17 (2): 4250.

Asokan, S., \& Ali, M.S. (2010). Foraging behavior of selected insectivorous birds in Cauvery Delta region of Nagapattinam District, Tamil Nadu, India. Journal of Threatened Taxa, 2 (2): 690-694.

Bibby, C.J., Bugress, N.D., \& Hill, D.A. (1992). Bird census techniques. Massachusetts: Academic Press Limited. Pp 257.

Buckland, S.T., Anderson, D.R., Burnham, K.P., Laake, J.L., Borchers, D.L., \& Thomas, L. (2001). Introduction to Distance Sampling. Oxford: Oxford University Press.

Ghani, A.N.A., Mohd-Shahwahid H.O., Rusli, M., Shukri, M., Faridah, H., \& Zakaria, M. (1999). Economic Valuation of Forest Goods and Services of Ayer Hitam Forest, Puchong, Selangor. Pertanika Journal of Tropical Agricultural Science, 2 (2): 147160.

Gill, F.B. (1990). Ornithology. New York: W. H. Freeman and Company.

International Union for Conservation of Nature, IUCN (2013). http://www.iucnredlist.org/.

Johnson, D.H. (2001). Habitat fragmentation effects on birds in grasslands and wetlands: a critique of our knowledge. Great Plains Research, 11: 211-231.

Karim-Dakog, A, Shahrim-Senik, M., Zubaid, A., \& Davison, G.W.H. (1997). Understorey avifauna of the UKM Forest Reserve, a fragmented and disturbed lowland rainforest. Malayan Nature Journal, 50(4), 337-346.

Krebs, C.J. (2009). Ecology: The experimental analysis of distribution and abundance. Glenview: Pearson Education Inc.

MacKinnon, J. \& Phillipps, K. (1993). A field guide to the: Birds of Borneo, Sumatra, Java and Bali. New York: Oxford University Press Inc.

Madinah, A., Abang, F., Mariana, A., Abdullah, M.T., \& Mohd-Azlan, J. (2014). Interaction of ectoparasites-small mammals in tropical rainforest of Malaysia. Community Ecology, 15 (1): 113-120.

Magurran, A.E. (2004). Measuring biological diversity. Oxford: Blackwell.

Mansor, M.S. \& Sah, S.A.M. (2012). Foraging patterns reveal niche separation in tropical insectivorous birds. Acta Ornithologica, 47 (1): 27-36.

Mohd-Azlan, J. \& Lawes, M.J. (2011). The effect of the surrounding landscape matrix on mangrove bird community assembly in north Australia. Biological Conservation, 144: 2134-2141.

Mohd-Azlan, J., Noske, R.A., \& Lawes, M.J. (2014). Resource Partitioning by Mangrove Bird Communities in North Australia. Biotropica, 46 (3): 331-340.

Myers, S. (2009). A field guide to the Birds of Borneo. London, United Kingdom: New Holland Publishers.

Peh, K.S.H., Sodhi, N.S., de Jong, J., Sekercioglu, C.H., Yap, C.A.M., \& Lim, S.L.H. (2006). Conservation value of degraded habitats for forest birds in southern Peninsular Malaysia. Diversity and Distributions, 12: 572-581.

Phillipps, Q. \& Phillipps, K. (2014). Phillipps' field guide to the birds of borneo: Sabah, Sarawak, Brunei and Kalimantan. Oxford: John Beaufoy Publishing Ltd.

Rahman, M.A., \& Tuen, A.A. (2006). The avifauna. In F. Abang, \& I. Das (Eds.), The Biodiversity of a Peat Swamp Forest in Sarawak (pp. 129-136). Kota Samarahan, Malaysia: Universiti Malaysia Sarawak. 
Ramli, R. (2004a). Green areas and avian species richness in University of Malaya campus, Peninsular Malaysia. Malaysian Journal of Science, 23: 7-13.

Ramli, R. (2004b). Temporal changes in diversity and similarity of bird communities of three forest fragments in an urban environment in Peninsular Malaysia. Malaysian Journal of Science, 23 (2): 8188.

Ramli, R., Ya'cob, Z., Aimi, F., \& Ezyan, N. H. (2012). How Valuable is Degraded Habitat to Forest Birds? A Case Study in Bachok, Kelantan. Pertanika Journal of Tropical Agricultural Science, 35 (3): 681693.

Remsen, J. V. \& Robinson, S. K. (1990). A classification scheme for foraging behavior of birds in terrestrial habitats. Studies in Avian Biology, 13: 144-160.

$\mathrm{R}$ Core Team (2013). R: A languange and environment for statistical computing. cran.r-project.org/doc/FAQ/R-FAQ.html. Downloaded on 06 June 2013.

Sodhi, N.S. (2002). A comparison of birds community of two fragmented and two continuous South East Asian forest. Biodiversity and Conservation, 11: 11051119.

Sodhi, N.S., Choo, J.P.S., Lee, B.P.Y.H., Quek, K.C., \& Kara, A.U. (1997). Ecology of a mangrove forest bird community in Singapore. The Raffles Bulletin of Zoology, 45 (1): 1-13.

Sorace, A. \& Visentin, M. (2007). Avian diversity on golf courses and surrounding landscapes in Italy. Landscape and Urban Planning, 81: 81-90.
Styring, A.R. \& Hussin, M.Z. (2004). Foraging ecology of woodpeckers in lowland Malaysian rain forests. Journal of Tropical Ecology, 20: 487-494.

Thomas, L., Buckland, S.T., Burnham, K.P., Anderson, D.R., Laake, J.L., Borchers, D.L., \& Strindberg, S. (2013). Distance Sampling. In A.H. El-Shaarawi, \& W.W. Piegorsch (Eds.), Encyclopedia of Environmetrics. West Sussex: John Wiley \& Sons, Ltd. Pp 544-551.

Wiens, J.A. (1989). The ecology of bird communities. Vol. 1: Foundations and Patterns. Cambridge: Cambridge University Press.

Zakaria, M. \& Zamri, R. (2008). Immediate effects of selective logging on the feeding guild of understorey bird species composition in Peninsular Malaysia. Malaysian Forester, 71: 139-151.

Zakaria M. \& Rajpar M.N.(2010). Bird Species Composition and Feeding Guilds Based on Point Count and Mist Netting Methods at The Paya Indah Wetland Reserve, Peninsular Malaysia. Tropical Life Sciences Research, 21 (2): 7-32.

Zainudin, S.R., Mustafa, K.A., Austin, D., Helmy, J., \& Lingkau, D.A. (2012). Urban tree diversity in Kuching North City and UNIMAS Kota Samarahan, Sarawak. Pertanika Journal of Tropical Agricultural Science, 35 (1): 27-32.

Zhang, S. (2011). On parametric estimation of population abundance for line transect sampling. Environmental Ecological Statistics, 18: 79-92. 